mucoide y aspecto brillante y, conformado por bacterias bacilares Gram-positivas sin disposición celular; y el morfotipo VP2, de colonias circulares beige mayores a $1 \mathrm{~mm}$ de diámetro, elevación convexa baja, borde entero, superficie lisa, consistencia cremosa y aspecto brillante $\mathrm{y}$, conformado por bacterias en forma de coco, Gram-positivas sin disposición celular. Estos dos morfotipos bacterianos serán identificados a nivel de especie y actividad biológica en $V$. planifolia. Este trabajo representa un aporte importante al conocimiento de la comunidad microbiana asociada a las especies de Vanilla nativas de Colombia.

\title{
Ceratobasidium lineages associated with two epiphytic orchids in Colombia
}

\section{Rafael Borges da Silva Valadares ${ }^{1 *}$, Elke Jurandy Bran Nogueira Cardoso ${ }^{1}$ \& Joel TuPAC OTERO $2,3,4$}

'Universidade de São Paulo, Escola Superior de Agricultura 'Luiz de Queiroz' (ESALQ), Departamento de Ciência do Solo, Piracicaba, São Paulo, Brazil; ${ }^{2}$ Grupo de Investigación en Orquídeas, Ecología y Sistemática Vegetal. Universidad Nacional de Colombia Sede Palmira, Palmira, Colombia; ${ }^{3} \mathrm{Facultad}$ de Ciencias Agropecuarias, Departamento de Ciencias Biológicas, Universidad Nacional de Colombia Sede Palmira, Palmira, Colombia; ${ }^{4}$ Instituto de Estudios Ambientales IDEA, Palmira, Colombia. Universidad Nacional de Colombia Sede Palmira, Palmira, Colombia; *Author for correspondence: rafaelbsvaladares@gmail.com

Extremely small orchid seeds lack endosperm, which is indispensable for seed germination. In nature the association with suitable mycorrhizal fungi provides simple sugars during the first steps of germination. Colombia is one of the countries with the greatest biodiversity of orchids, with an estimate of 3,200 species, but few studies on orchid mycorrhiza have been performed. In our study we isolated and sequenced the ITS rDNA region of fungi from two sympatric, epiphytic orchids of Colombia, Ionopsis utricularioides and Psygmorchis pusilla, both belonging to subtribe Oncidiinae. All sequences were recognized as belonging to the genus
Ceratobasidium, known to be a common orchid mycorrhizal fungus in both tropical and temperate orchids. One sequence was $100 \%$ similar to fungi isolated from I. utricularioides in Costa Rica in a previous study. Ionopsis utricularioides was confirmed to be a specialist, associating with only one clade of mycorrhizal fungi, whereas Psygmorchis pusilla proved to be a generalist, associating with three clades. This finding confirms that variation in mycorrhizal specificity is an important factor in coexistence of orchids. The high affinity between the subtribe Oncidiinae and Ceratobasidium was also confirmed. 